\title{
COMMUNITY-BASED EDUCATION PROGRAM ON KNOWLEDGE AND SELF-EFFICACY OF TYPE 2 DIABETES MELLITUS' PATIENTS IN BANDUNG
}

\author{
Citra Windani Mambang Sari ${ }^{1}$ \\ ${ }^{1}$ Nursing Lecturer of Faculty of Nursing, Padjajaran University, Indonesia \\ e-mail :ners_citra@yahoo.com
}

\begin{abstract}
Introduction: Type 2 Diabetes Mellitus was a chronic disease have complicated. Amount of patient Type 2 Diabetes Mellitus (DM) was increased. Knowledge and self-efficacy is mainly important for self-care behavior. The purpose of this study was aimed to examine knowledge, and self-efficacy among patients with Type 2 DM in Bandung, Indonesia. Methods: The research was a quasi-experimental with pre and posttest control group. Sixty two type 2 DM were recruited from 8 working area Primary Health Centers in Bandung who have diagnosed DM, using purposive sampling technique. Knowledge questionnaire from Michigan Diabetes Research and Training Center's Brief Diabetes Knowledge Test, Self-efficacy were measured by the developed Stanford Patients Education Research Center. Both of questionnaires comprised five dimensions: nutrition, sport and activity, drugs and glucose monitoring. Patients of in intervention group received 2 weeks Diabetes Mellitus education program be given healthcare workers. Techniques used in this program consisted of community-based education, goal setting, follow-up and face-to-face interview. Data were analyzed by independent t-test. Results: There are significantly different of knowledge and self-efficacy after community-based education program in intervention $(\mathrm{M}=9.26, \mathrm{SD}=2.8 ; \mathrm{M}=53.26, \mathrm{SD}=10.50)$ and control group $(\mathrm{M}=7.39, \mathrm{SD}=2.4 ; \mathrm{M}=36.74, \mathrm{SD}=4.49)$. This study revealed that communitybased education program significantly improved self-efficacy $(p=0.000)$ but not improved for knowledge $(p=0.180)$. Conclusion: These findings indicated that Knowledge and Self-efficacy of type 2 Diabetes Mellitus patients in Bandung required improvement. Therefore, further study regarding the effective in improving knowledge and self-efficacy type 2 Diabetes Mellitus is extremely needed.
\end{abstract}

Keywords: Diabetes mellitus, knowledge, self-efficacy, community-based

\section{INTRODUCTION}

Along with technological advances in the world of health, there has been a shift in the pattern of disease in the world. One of them is the number of lifestyle diseases caused increasing compared with the number of infectious disease or other disease. One of the diseases caused by lifestyle are Diabetes Melitus (DM). Based on data from the WHO in 2010, the number of diabetes patients in the world is 8.4 million and Indonesia ranks fourth in the number of DM patients in the world (WHO, 2010). Based on data from the International Diabetes Federation (IDF) in 2011, Indonesia was ranked 9th in the world. Based on data Riskesdas (2007) West Java Province was ranked
12 in Indonesia with a prevalence of 3.7\% (Riskesdas, 2007).

The research about treatment of DM education program has much to do with a lot of measurement results. All the research done on the individual patient with a hospital setting (Vatankhah et al, 2009 and Kurniawan et al, 2011), at home (Lincoln et al, 2008, Sari et al, 2012, and Susanti et al, 2011). From the four studies only Susanti et al (2011) and Sari et al (2012) which involves the family but only in doing foot care education, while Susanti et al (2011) in the management of DM. There are no research on how the knowledge and self-efficacy in patients with DM involving community. According to Friedman (2010), the 
community can be involved as targets for patient's self-efficacy because the community can be a driver of the other members of the community to perform a behavior.

DM management education by involving the community is also very important for other members of the community, considering DM is a hereditary disease that a risk for other members of the community. In addition, DM is a chronic disease that decreases the ability of the patient, so that if the community is involved in this educational program, the community can assist in the management of DM and improve knowledge and selfefficacy in patients This study aimed to identify the effect of communitybased education program on knowledge and elf-efficacy in patients with DM in Bandung.

\section{METHODS}

The method used is a quasiexperimental design using techniques Cluster randomized with two groups: the control and the intervention. The intervention group received a community-based education program on the management of DM, while the control group received the regular program Data were collected twice, pre and post-test. This research was performed 62 patients from 8 working area Public Health Center Bandung, West Java, Indonesia. Working areas Public Health Center are Pasir Kaliki, Pasundan, Ibrahim Adjie, Garuda, Griya Antapani, Arcamanik, Ujung Berung Indah and Sekejati. The measurement was done by home visit. The subjects were selected by purposive sampling method. The inclusion criteria were: patients have diagnosed with $\mathrm{DM}$, independent, patients have no complication.

Community-based education for DM patients had 2 sessions of intervention: cadres training and community-based education program. Community-based education program consist of 4 week. Before education program, respondent answered pretest. First week, education program was given by cadres about DM, exercise, diet, drugs and control blood glucose. Second, third and fourth week was home visit with cadres. Then, respondent answered post-test.

Research tool is modified $\mathrm{n}$ three parts. First, it assess demographic data: age, sex, marital status, job, education, history of smoking, duration of diabetes, foot symptom, comorbid disease, BMI. Second, knowledge questionnaire from Michigan Diabetes Research and Training Center's Brief Diabetes Knowledge Test. This 15-knowledge questionnaire is multiple choices questions. So, the highest score was a 15 and the lowest 0 . Third, it is summary of Diabetes Self Care Activity and Diabetes Self-Management Instrument. This 29-self management DM questionnaire has each question included 4 following items: I always do, sometimes do, seldom do and never with $0,1,2$ and 3 score. The highest score was a 87 and the lowest 0 . Fourth, Self-efficacy were measured by the developed Stanford Patients Education Research Center. This 12 care self-efficacy questions has 5 scales: strongly confident, moderately confident, confident, moderately not confident with score 0-3. The highest score was a 36 and the lowest 0 . Both of questionnaire comprised five dimensions: nutrition, sport and activity, drugs and glucose monitoring. Questionnaires are in Indonesian and tested for validity and reliability (Sari et al. 2012). Higher score indicates the better self-efficacy and knowledge about DM. Data were analyzed by descriptive statistics, independent sample t-test and ANOVA. 


\begin{tabular}{|c|c|c|c|c|c|c|}
\hline \multirow[t]{2}{*}{ Variabel } & \multicolumn{2}{|c|}{$\begin{array}{c}\text { Control } \\
(n=31)\end{array}$} & \multicolumn{2}{|c|}{$\begin{array}{c}\text { Intervention } \\
(\mathbf{n}=\mathbf{3 1})\end{array}$} & \multirow[t]{2}{*}{$\mathbf{x}^{2}$} & \multirow[t]{2}{*}{ p-Value } \\
\hline & $\mathbf{f}$ & $\%$ & $\mathbf{f}$ & $\%$ & & \\
\hline \multicolumn{7}{|l|}{ Age } \\
\hline 40 - 59 years old & 19 & 61.3 & 21 & 67.7 & $0.282^{\mathrm{a}}$ & 0.791 \\
\hline $59-69$ years old & 12 & 38.7 & 10 & 32.3 & & \\
\hline \multicolumn{7}{|l|}{ Gender } \\
\hline Male & 10 & 32.3 & 8 & 25.8 & $0.313^{\mathrm{a}}$ & 0.576 \\
\hline Female & 21 & 67.7 & 23 & 74.2 & & \\
\hline \multicolumn{7}{|l|}{ Status } \\
\hline Single & 2 & 6.5 & 3 & 9.7 & $0.127^{\mathrm{c}}$ & 1.000 \\
\hline Married & 24 & 77.4 & 24 & 77.4 & & \\
\hline Divorced & 1 & 3.2 & 0 & 0 & & \\
\hline Widow & 4 & 12.9 & 4 & 12.9 & & \\
\hline \multicolumn{7}{|l|}{ Ethnic } \\
\hline Sundanese & 30 & 96.8 & 26 & 83.9 & $2.952^{\mathrm{b}}$ & 0.185 \\
\hline Java & 1 & 3.2 & 5 & 16.1 & & \\
\hline \multicolumn{7}{|l|}{ Status of Employment } \\
\hline Unemployment & 19 & 61.3 & 20 & 64.5 & $1.016^{\mathrm{c}}$ & 0.253 \\
\hline Labor & 1 & 3.2 & 6 & 19.4 & & \\
\hline Government employee & 0 & 0 & 1 & 3.2 & & \\
\hline Private & 0 & 0 & 1 & 3.2 & & \\
\hline Entrepreneur & 3 & 9.7 & 3 & 9.7 & & \\
\hline Other & 8 & 25.8 & 0 & 0 & & \\
\hline \multicolumn{7}{|l|}{ Education } \\
\hline Illiterate & 2 & 6.5 & 1 & 3.2 & $0.381^{\mathrm{c}}$ & 0.999 \\
\hline Elementary & 16 & 51.6 & 17 & 54.8 & & \\
\hline Junior & 4 & 12.9 & 7 & 22.6 & & \\
\hline Senior & 8 & 25.8 & 6 & 19.4 & & \\
\hline University & 1 & 3.2 & 0 & 0 & & \\
\hline
\end{tabular}

Table 1. Frequency Distribution Analysis and Homogeneity Test Characteristics of Respondents on Intervention Group and Control Group in Bandung the study period from November to December $2013(n=62)$

Based on table 1, most of respondent in control group and intervention group aged 40-59 years old. Most of respondent in control group and intervention group are female. Most of respondent in control group and intervention group are married. Most of respondent in control group and intervention group are Sundanese. Most of respondent in control group and intervention group are unemployed and most of them have graduated in elementary school.
Table 2 explains most of respondents in both group have high glucose and they used to go walking as exercise. Most of respondents in control and intervention group never smoking. Most of respondent in control and intervention group never got educational program. Most of respondent in control and intervention group have comorbid disease. Most of respondent in control and intervention group have more than three years of duration DM. 


\begin{tabular}{|c|c|c|c|c|c|c|}
\hline \multirow[t]{2}{*}{ Variabel } & \multicolumn{2}{|c|}{$\begin{array}{c}\text { Control } \\
(\mathrm{n}=31)\end{array}$} & \multicolumn{2}{|c|}{$\begin{array}{c}\text { Intervention } \\
(\mathrm{n}=\mathbf{3 1})\end{array}$} & \multirow[t]{2}{*}{$\mathbf{X}^{2}$} & \multirow[t]{2}{*}{ p-Value } \\
\hline & $\mathbf{f}$ & $\%$ & $\mathbf{f}$ & $\%$ & & \\
\hline \multicolumn{7}{|l|}{ Blood glucose } \\
\hline Low & 0 & 0 & 1 & 3.2 & $0.381^{\mathrm{b}}$ & 0.999 \\
\hline Normal & 6 & 19.4 & 2 & 6.5 & & \\
\hline High & 25 & 80.6 & 28 & 90.3 & & \\
\hline \multicolumn{7}{|l|}{ Exercise } \\
\hline Never & 4 & 12.9 & 12 & 38.7 & $1.016^{\mathrm{b}}$ & 0.253 \\
\hline Walking & 24 & 77.4 & 18 & 58.1 & & \\
\hline Gym & 2 & 6.5 & 1 & 3.2 & & \\
\hline Bycycle & 1 & 3.2 & 0 & 0 & & \\
\hline \multicolumn{7}{|l|}{ Smoking History } \\
\hline Never & 22 & 71.0 & 24 & 77.4 & $0.254^{\mathrm{b}}$ & 1.000 \\
\hline Former & 6 & 19.4 & 3 & 9.7 & & \\
\hline Still smoking & 3 & 9.7 & 4 & 12.9 & & \\
\hline \multicolumn{7}{|c|}{ DM educational program } \\
\hline Yes & 2 & 6.5 & 6 & 19.4 & $2.296^{\mathrm{a}}$ & 0.255 \\
\hline Never & 29 & 93.5 & 25 & 80.6 & & \\
\hline \multicolumn{7}{|l|}{ Comorbid Disease } \\
\hline Yes & 19 & 61.3 & 23 & 74.2 & $1.181^{\mathrm{a}}$ & 0.237 \\
\hline No & 12 & 38.7 & 8 & 25.8 & & \\
\hline \multicolumn{7}{|c|}{$\begin{array}{l}\text { Monofilament sensation } \\
\text { on right foot }\end{array}$} \\
\hline Yes, all & 26 & 83.9 & 20 & 64.5 & $0.762^{\mathrm{b}}$ & 0.607 \\
\hline Yes, one and two & 6 & 19.4 & 4 & 12.9 & & \\
\hline No & 5 & 16.1 & 1 & 3.2 & & \\
\hline \multicolumn{7}{|c|}{$\begin{array}{l}\text { Monofilament sensation } \\
\text { on left foot }\end{array}$} \\
\hline Yes, all & 24 & 77.4 & 21 & 67.7 & $0.381^{\mathrm{b}}$ & 0.999 \\
\hline Yes, one and two & 5 & 16.1 & 5 & 16.1 & & \\
\hline No & 2 & 6.5 & 5 & 16.1 & & \\
\hline \multicolumn{7}{|c|}{ Duration of Diabetes } \\
\hline$<3$ years & 11 & 35.5 & 15 & 48.4 & $1.060^{\mathrm{a}}$ & 0.303 \\
\hline$>3$ years & 20 & 64.5 & 16 & 51.6 & & \\
\hline
\end{tabular}

Note $: \mathrm{a}=$ Chi-Square, $\mathrm{b}=$ Kolmogorov-Smirnov $Z$
Table 2. Frequency Distribution Analysis and Homogeneity Test Characteristics of Respondents on Intervention Group and Control Group in Bandung the study period from November to December $2013(\mathrm{n}=62)$

\begin{tabular}{lcccc}
\hline \multirow{2}{*}{ Variabel } & \multicolumn{2}{c}{ Control Group } & \multirow{2}{*}{ T } & p-value \\
\cline { 2 - 3 } & $\begin{array}{c}\text { Mean (SD) } \\
\text { Keafer Mean }\end{array}$ & $\begin{array}{c}\text { After } \\
\text { (SD) }\end{array}$ & & \\
\hline Knowledge & $7.39(2.741)$ & $8.10(2.70)$ & -7.473 & 0.000 \\
\hline Self-Efficacy & $27.74(5.871)$ & $27.70(5.06)$ & 2.875 & 0.007 \\
\hline $\begin{array}{l}\text { Note }: \mathrm{t}=\text { paired } t \text {-test, } \mathrm{df}=30 \\
\text { Table 3. Test average difference of Knowledge, Self-efficacy among respondents about } \\
\text { diabetes mellitus before and after the intervention in the control group }\end{array}$
\end{tabular}


Table 3 illustrates the different test average of knowledge and self-efficacy in patients with diabetes mellitus before and after the intervention in the control group. The average value of knowledge before it is 7.39 (2741) and after 8:10 intervention (2.70). The average value of the respondents' knowledge of the control group there were significant changes $(p=0.00)$. The value of selfefficacy before the intervention in the control group was $27.74(5,871)$ while the post is $27.70(5: 06)$. The average value of respondents' self-efficacy in the control group there were significant changes $(p=0.007)$.

\begin{tabular}{lcccc}
\hline \multirow{2}{*}{ Variabel } & \multicolumn{2}{c}{ Intervention Group } & \multirow{2}{*}{ T } & p-value \\
\cline { 2 - 3 } & $\begin{array}{c}\text { Before } \\
\text { Mean (SD) }\end{array}$ & $\begin{array}{c}\text { After Mean } \\
\text { (SD) }\end{array}$ & & \\
\hline Knowledge & $8.35(2.138)$ & $9.26(2.898)$ & -7.473 & 0.067 \\
\hline Self-Efficacy & $29.84(6.822)$ & $36.74(4.494)$ & -5.336 & 0.000 \\
\hline Note : $\mathrm{t}=$ paired & t-test, $\mathrm{df}=30$ & & &
\end{tabular}

Table 4. Average Difference Test Knowledge, Self-Efficacy on respondents about diabetes mellitus before and after the intervention in the intervention group

\begin{tabular}{lcccc}
\hline \multirow{2}{*}{ Variabel } & Control & Intervention & \multirow{2}{*}{ T } & p-value \\
\cline { 2 - 3 } & Mean (SD) & Mean (SD) & & \\
\hline Before & $7.39(2.741)$ & $8.35(2.138)$ & -1.550 & 0.126 \\
\hline After & $8.10(2.70)$ & $9.26(2.898)$ & -1.632 & 0.108 \\
\hline Note $: \mathrm{t}=$ independent $t$-test, $\mathrm{df}=60$ & & &
\end{tabular}

Table 5. Test average difference in respondents Knowledge about diabetes mellitus before and after the intervention in the control group and intervention

\begin{tabular}{lcccc}
\hline \multirow{2}{*}{ Variabel } & $\begin{array}{c}\text { Control } \\
\text { Group }\end{array}$ & $\begin{array}{c}\text { Intervention } \\
\text { Group }\end{array}$ & T & p-value \\
\cline { 2 - 3 } & Mean (SD) & Mean (SD) & & \\
\hline Before & $27.74(5.871)$ & $29.84(6.822)$ & -1.297 & 0.220 \\
\hline After & $27.70(5.06)$ & $36.74(4.494)$ & -8.009 & 0.000 \\
\hline Note $\cdot t=$ independent $t$-test $\mathrm{df}=60$ & &
\end{tabular}

Note $: \mathrm{t}=$ independent $t$-test, $\mathrm{df}=60$

Table 6. Test average difference in respondents Self efficacy of diabetes mellitus before and after the intervention in the control group and intervention

Table 4 illustrates the different test average variable knowledge and self-efficacy in patients with diabetes mellitus before and after the intervention in the intervention group. The average value of knowledge before it is 8.35 (2138) and after the intervention 9:26 (2898). The average value of the respondents' knowledge in the intervention group there was no significant change $(p=0.067)$. The value of self-efficacy before the intervention in the control group was

29.84 (6822) while the post is $36.74(4,494)$. The average value of respondents' self-efficacy in the control group there were significant changes $(p=0.000)$. Either Table 5 or Table 6 showed there were no significant difference in the mean value of knowledge before the intervention in both groups $(p=0.220)$. The average value of self-efficacy after the intervention significantly different $(\mathrm{p}=$ 0.000).

\section{DISCUSSION}

This study is a model application health education in community-based education program has been conducted by researchers in accordance with the theory, which involves a cadres in the process of education given to the patient and accompanied by 
researchers. This study confirmed the results of the research of Jack et al (2004) found that Diabetes SelfManagement Education (DSME) using methods, guidance, counseling and behavioral interventions can improve knowledge of diabetes mellitus and improving the skills of individuals and families in managing disease Diabetes mellitus. The involvement of cadres in controlling also have an important role in alerting and improve the knowledge and self-efficacy. The involvement of cadres in controlling the self-care respondents also have an important role in reminding and improving the knowledge, self-efficacy. In addition, the module given to the respondent so that the respondent can be read again with family. This makes the process of discussion among families, cadres and respondents. This discussion could add and update their knowledge and information about DM and improve their self-efficacy.

The information is a power to change attitudes of individuals that could open one's mind through reasoning, thinking and deeper understanding (Sarafino, 1998). The results showed different test level of self-efficacy before and after the intervention program, communitybased self-care education in the intervention group concludes significant difference. This is consistent with previous research done by Corbett (2003) and Perrin et al (2009) and Sari et al (2012) on the behavior of foot care DM. Confidence (self-efficacy) also has an important contribution in improving self-care behavior of the respondents and the confidence of cadres carry out the assistance process in patients with $\mathrm{DM}$. This is consistent with the theory of self-efficacy from Bandura, the belief in the ability of the respondent may regulate or exhibit behaviors that are considered as a destination (Passer \& Smith, 2004). In addition, the strategy of self-care education program uses a community-based modules. After education is completed, the respondent is directed by cadres for planning activities to perform self-care behaviors DM, with the cadre as a controller. The main purpose of planning the activities specified respondent is the increased confidence (self-efficacy) of the respondents so that the respondent can achieve healthy behaviors (Bodenheimer et al, 2007).

According to Schultz and Schultz (2005) that there is a difference between people who have low self efficacy with high self-efficacy. Someone who has low self-efficacy would tend to feel there is no hope, unable to make arrangements on the circumstances that occurred in his life. By the time they face obstacles, they will quickly give up if the first attempt has failed. Someone who has very low self-efficacy will not make any effort to overcome the existing barriers, because they believe that their actions will not bring any influence. On the other hand someone who has a high self-efficacy believe that they can cope with the incident and the situation effectively. They have high confidence with regard to their ability compared with those having low selfefficacy. Someone who has a high selfefficacy see the difficulties that exist as a challenge rather than threatening.

\section{CONCLUSION}

Mean value of the respondents' knowledge of the control group and the intervention after intervention was not significantly different. Mean value of respondents' self-efficacy in the control group and the intervention after intervention is different significantly. The existence of educational programs, community-based knowledge and self-efficacy in patients with diabetes mellitus by involving cadre of which further research to take the setting of a broader research so as to provide the characteristics of different samples and sample sizes bigger so visible increase in knowledge and self-efficacy better again. In addition further research can apply the method of this communitybased education program with a longer 
intervention period and integrate the program with existing programs in the health center.

\section{REFERRENCES}

American Diabetes Association. (2010). Fitness. Available at :http:/ / care.diabetesjournals. org (Diakses pada 28 Juni 2013)

(2013). Physical Activity is Important. Available at :http:/ / care.diabetesjournals. org (Diakses pada 28 Juni 2013)

Bantle, J.P., Juddith, W.R., Ann, L.A., Caroline, M.A., Nathaniel, G.C., Marrion, J.F., Byron, J.H.,et al. (2008). Nutrion Recommendation and Interventions for Diabetes. Available at : diabetesjournals. org (diakses pada 26 Juni 2013)

Bodenheimer T, Lorig K, Holman H, Grumbach K. 2002. Patients Self Management of Chronic Disease in Primary Care. American Medical Association (reprinted) JAMA,Vol 288,No. 19. Available : http://jama.amaassn.org/content/288/19/2469.full. pdf + html

Depkes RI. 2009. Tahun 2030 Prevalensi Diabetes Melitus di Indonesia Mencapai 213 juta Orang Tahun (online). Available : http://www.depkes.go.id/index.php/ berita/press-release/414-tahun-2030prevalensi-diabetes-melitus-di-indonesiamencapai-213-juta-orang.html

Depkes RI. 2010. Diabetes Melitus dapat Dicegah (online). Available : http://www. depkes.go.id/index.php/berita/pressrelease/1314-diabetes-melitus-dapatdicegah.html

Funnel MM and Anderson RM. 2004. Empowerment and Self Management of Diabetes. Clinical Diabetes- Volume 22, Number 3, 2004. Available: http: / / clinical.diabetesjournals.org/ content/22/3/123.full.pdf+html

Friedman MM, Bowden VR, Jones EG. 2010. Buku Ajar Keperawatan Keluarga Riset, Teori, Praktek. EGC, Jakarta.

Jack Jr L, Liburd L, Tirzah S, Airhihebbuwa CO. 2004. Understanding the Environmental Issues in Diabetes Self-Management Education Research : A Reexamination of 8 Studies in Community-Based Settings. Annals of Internal Medicine Volume 140 Number 11. Available http://www.annals. org/content/140/11/964.full.pdf

Kurniawan T, Sae-Sia W, Maneewat K,
Petpichetchian W. 2011. The Effect of a self management Support Program on The Achievemnet Goal in Diabetic Foot Care Behaviours in Indonesian Diabetic Patients. Nurse Media Journal of Nursing, 1, 2 , 195-210.

Lincoln NB, Radford KA, Game FL, Jeffcoate WJ. 2008. Education for Secondary Prevention of Foot Ulcers in people with Diabetes : a randomized Controlled Trial. Diabetologia, 51, 1954-1961.

McGowan, P. 2011. The Efficacy of Diabetes Patient Education and Self-Management Education in DM type 2. Canadian Journal of Diabetes35 (1) 46-53.

Perkeni. 2011. Penatalaksanaan Diabetes Melitus. PB. Perkeni. Jakarta.

Riskesdas. (2007). Laporan Nasional Kesehatan 2007. Available at : google.com (diakses 06 Desember 2012)

Sari, CWM, Haroen H, Nursiswati. 2012. Pengaruh program edukasi berbasis keluarga terhadap perilaku perawatan kaki pada pasien Diabetes Melitius di Wilayah Puskesmas Pasirkaliki Bandung. Thesis Pasca Sarjana BKU Komunitas Universitas Padjadjaran. Tidak dipublikasikan.

Smeltzer and Bare. (2002). Buku Ajar Keperawatan Medikal Bedah Brunner\&.Suddarth edisi 8. Jakarta: EGC.

Soegondo, S. (2006). Penatalaksanaan Diabetes Mellitus Terpadu. Jakarta : FK UI

Sudoyo, dkk. (2007). Buku Ajar Ilmu Penyakit Dalam. Jakarta : Pusat penerbitan Ilmu Penyakit Dalam FK UI

Susanti, S; Haroen H; Juniarti N. 2011. Pengaruh Diabetes Self Management Education (DSME) berbasis keluarga pada tingkat perawatan diri Pasien Diabetes Melitus di Kota Bandug. Tesis. Tidak dipublikasikan .

Toobert, D.J.,Sarah E.H.,Russell E.G. (2000). The summary of diabetes self-care activities measure. Diabetes Care, 23(7), 943-950 Available at : Proquest (diakses pada 02 Januari 2013)

Vatankhah N, Khamseh ME, Noudeh YJ, Aghili R, Baradaran HR, Haeri NS. 2009. The Effectiveness of Foot Care Education on People With Type 2 Diabetes in Tehran, Iran. Primary Care Diabetes 3, 73-77.

World Health Organization. (2010). Diabetes. Available at:http://www.who.int/topics / diabetes-melitus (diakses pada 03 Oktober 2012 